\title{
Bovine Papillomavirus-1
}

National Cancer Institute

\section{Source}

National Cancer Institute. Bovine Papillomavirus-1. NCI Thesaurus. Code C14337.

A type of Bovine Papillomavirus. 